\title{
Genetic Gain and Gene Diversity Following Thinning in a Half-Sib Plantation
}

\author{
By A. Fedorkov ${ }^{1)}$, D. LindGren ${ }^{2)}$ and A. DAVID ${ }^{3)}$
}

(Received $3^{\text {rd }}$ March 2005)

\begin{abstract}
Status number, gene diversity, inbreeding coefficient and genetic gain were calculated following phenotypic rogueing of different intensities in a half-sib progeny plantation of Scots pine (Pinus sylvestris L.). Across most selection intensities the status number, gene diversity and genetic gain remained favorably high while the inbreeding coefficient was remarkably stable. It is suggested that phenotypic selection in half-sib progeny tests or plantations with unknown pedigrees, can be used to manage seed collection areas or as a component in low-input breeding without a fast build up of coancestry or inbreeding, provided the initial number of progenies of unrelated parents is sufficiently high and that a high number of these families are retained with a few individuals per family.
\end{abstract}

Key words: half-sib plantation, status number, inbreeding, gene diversity, genetic gain, low-input breeding, seed collection area, Scots pine.

\section{Introduction}

In many situations tree improvement technology is severely limited by available resources. When using low input options, like half-sib plantations, intensive thinning is necessary to obtain even modest genetic gain. As test material half-sib families are usually used for field genetic testing. The same kind of material is planted or sown to establish seedling seed orchards. The flexible strategy that lies somewhere between a seedling seed orchard and a progeny test is a breeding seedling orchard (BARNES, 1995). LINDGREN (2000) suggested the gene resource plantation, as a low-input variant of a breeding seed orchard. Low-input breeding is considered inexpensive, convenient, simple, robust, local, and requires little record keeping or central control (LiNDGREN, 2003). Gene resource plantations may be established from open pollinated selected trees as progeny tests and seed orchards, or as a mixture of unidentified half-sib families similar to operational plantations. Regardless, gene resource plantations should be subjected to intense rogueing so that desirable, well-adapted phenotypes are favored. When rogueing gene resource plantations the relationships between genetic gain, inbreeding and genetic diversity must be well understood. These factors must be predicted to adequately

\footnotetext{
1) Institute of Biology, Komi Science Center, Russian Academy of Sciences, 167982, Kommunist. st., 28, Syktyvkar, Komi Republic, Russia.

2) Department of Forest Genetics and Plant Physiology, Swedish University of Agricultural Sciences, SE-901 83 Umeå, Sweden.

3) Department of Forestry, North Central Research and Outreach Center, University of Minnesota, 1861 Highway 169 East Grand Rapids, MN 55744, USA.
}

manage gene resource plantations and to plan seed collection. The aim of this study was to simulate a lowinput breeding scenario and calculate various genetic parameters following different thinning intensities in a half-sib progeny test.

\section{Material and Methods}

\section{Experimental data}

This study used a Scots pine progeny trial located at latitude $64^{\circ} 01^{\prime} \mathrm{N}$ and longitude $20^{\circ} 34^{\prime} \mathrm{E}$ in northern Sweden (Persson, 1999). The progeny trial was established in 1986 at $1.5 \times 2.2 \mathrm{~m}$ spacing on a site with an estimated site index of T20 (that means that upper height of 100 -year-old pine is predicted to be 20 meters). This trial was comprised of 98 open-pollinated families of Scots pine plus trees selected from 24 naturally or artificially regenerated stands situated between $65^{\circ} 28^{\prime} \mathrm{N}$ and $66^{\circ} 45^{\prime} \mathrm{N}$. One-year old seedlings were planted using a single tree plot design with 15 replications although not all families were fully replicated. In 1995, ten years after planting, tree-height data were collected and used as the basis for the theoretical rogueing calculations.

\section{Calculations and Assumptions}

A progeny trial of open-pollinated families consists of a number of half-sibs. It is assumed there is no inbreeding and no relatedness except that half-sibs share one parent (seed parent). The height of the trees is known and it is assumed the trial is rogued using truncation selection for height. The number of trees in each family is $n_{i}$, where $i$ is the family identification.

The probability that two different trees taken at random are related as half-sibs is calculated. The probability that the first tree belongs to family $i$ is $n_{i} / n_{T}$. The probability that the second tree also belongs to family $i$ is $\left(n_{i}-1\right) /\left(n_{T}-1\right)$. Thus the probability that both the first and the second tree belong to family $i$ is $n_{i}$ $\left(n_{i}-1\right) /\left(\left(n_{T} n_{T}-1\right)\right)$. The probability that any two trees in the trial both belong to the same family is obtained by summing over all families, or

$$
\frac{\sum n_{i}\left(n_{i}-1\right)}{n_{T}\left(n_{T}-1\right)}
$$

The following calculations refer to different variations of coancestry, which is the probability that two genes drawn from individuals are identical by descent. Selfcoancestry is the coancestry of an individual with itself. Group coancestry is the probability that two genes drawn from a group of individuals are identical by descent, that is, the average of all possible coancestries among a group of individuals including self-coancestry. 
Average pair-coancestry refers to group coancestry excluding self-coancestry. Therefore, group coancestry is the sum of self-coancestry and average pair-coancestry. The coancestry for half-sibs is $1 / 8$, and the probability that a gene in one individual is identical by descent to a gene in a half-sib is $1 / 8$. Thus, the average pair-coances$\operatorname{try}(\theta)$ for half-sibs is calculated as $1 / 8$ of the probability that any two trees in the same trial belong to the same family. Half-sibs share two grandparents out of four, thus the probability that genes taken from half-sibs originate from the same grandparent is $1 / 4$. Given that it is the same grandparent, there are two possible genes. Thus it is one chance in eight that genes taken from half-sibs are identical copies of the same gene in the grandparent generation, thus coancestry for half-sibs is set to $1 / 8$

$$
\bar{\theta}=\frac{\sum n_{i}\left(n_{i}-1\right)}{8 n_{T}\left(n_{T}-1\right)}=F
$$

Because the level of inbreeding in a population is correlated to the relatedness of the individuals the expected inbreeding coefficient $(F)$ of the seed resulting from random mating among the remaining trees in the progeny trial (without selfing) is the same as the average pair-coancestry of the parents.

Group coancestry $(\Theta)$ for the half-sib population was calculated as

$$
\Theta=\frac{0.5 \sum n_{i}+0.125 \sum n_{i}\left(n_{i}-1\right)}{\left(\sum n_{i}\right)^{2}}
$$

Group coancestry can also be used to derive gene diversity, $G D$, which is defined as the probability that genes are not identical by descent in the gene pool. Gene diversity is expressed as

$$
G D=1-\Theta
$$

Status number $\left(N_{s}\right)$ is an effective number defined by LINDGREN et al. (1996) as half the inverse of the group coancestry

$$
N_{s}=\frac{0.5}{\Theta}
$$

The factor 0.5 in equation (5) is logical considering that individual trees have two genes and the transformation of a gene pool characteristic to one considering trees has to include a factor $2(0.5)$. Status number describes the actual population in terms of a theoretical population size that is unaffected by inbreeding or relatedness. The degree to which status number is smaller than the census number depends on the amount of inbreeding and relatedness in the population. For example, status number is the same as census number for a population without inbreeding or relatedness. It is often practical to relate status number with census number $(N)$ in the population, thus relative status number $\left(N_{r}\right)$ is

$$
N_{r}=\frac{N_{s}}{N}
$$

The statistical model used to estimate the variance components was:

$$
Y_{i j l}=\mu+R_{j}+F_{i}+\varepsilon_{l}
$$

where $Y$ is the total tree height, $\mu$ is the overall mean, $R_{j}$ and $F_{i}$ are the effects of replication $(j=1 \ldots 15)$ and family $(i=1 \ldots 98)$ respectively, and $\varepsilon_{l}$ is the experimental error. Estimates of variance components were obtained with the computer program ASREML (GILMOUR et al., 2001). The formula for estimated genetic gain $(\Delta G)$ was calculated as

$$
\Delta G=S h^{2}
$$

where the selection differential $(S)$ is the difference between the means of the selected trees and the overall trial mean and $h_{i}^{2}$ is the narrow-sense heritability calculated as

$$
h_{i}^{2}=\frac{4 \sigma_{F}^{2}}{\sigma_{F}^{2}+\sigma_{\varepsilon}^{2}}
$$

where $\sigma_{F}^{2}$ is the variation due to family and $\sigma_{\varepsilon}^{2}$ is the remainder of the genetic variation plus variation due to experimental error.

\section{Results and Discussion}

Average plantation height was $3.2 \mathrm{~m}$ and narrow sense heritability for height was calculated as 0.18 . Using a hypothetical truncation selection at $0.1 \mathrm{~m}$ intervals 17 data sets were created and various parameters including selection intensity were calculated for each (Table 1).

Status number, $N_{s}$, which describes the theoretical effective number of unrelated individuals, decreased as the census number of individuals in the progeny test decreased. However, the number of families retained remained fairly constant across most selection intensities (Fig. 1). This was possible because many families contained individual trees that were both taller and shorter than the truncation threshold even at high selection intensities. Therefore, even under strong selection intensities each retained family contained only one or two half-sibs. The combined effect of high family number and low number of individuals per family kept $\mathrm{Ns}$ higher than would be expected from family or combined index selection.

Estimated genetic gain ranged from $1.9 \%$ at a $73.9 \%$ selection intensity $\left(N_{s}=265\right)$ to $10.0 \%$ at a $0.3 \%$ selection intensity $\left(N_{s}=4\right)$. These values are within the range of reported height gains for Scots pine (KRUSCHE et al., 1980; SQUillace et al., 1975) and indicate that this particular plantation is an adequate representation of Scots pine progeny tests. Genetic gains achieved by phenotypic thinning may exceed these estimates as selective rogueing can produce much higher heritabilities than calculated from the entire plantation (MATHESON and RAYMOND, 1984). Additional genetic gains could be realized if seed was collected from only the phenotypically best females in gene resource plantations (HARwooD et al., 1996).

The inbreeding coefficient was relatively constant and very low across most selection intensities and genetic gain estimates (Fig. 2). Because inbreeding depression is considered to be linearly related to $F$ (e.g. WU et al., 1998; Sorensen, 1997; Durel et al., 1996) these data suggest that losses in height due to inbreeding depres- 
Table 1. - Various parameters associated with truncation selection at different selection intensities in a 98 family half-sib Scots pine progeny test

\begin{tabular}{c|c|c|c|c|c|c|c|c|c|c|c|c|c|c|c|c|c}
\hline $\begin{array}{c}\text { Threshold thinning } \\
\text { value (m) }\end{array}$ & 0.0 & 2.0 & 2.1 & 2.2 & 2.3 & 2.4 & 2.5 & 2.6 & 2.7 & 2.8 & 2.9 & 3.0 & 3.1 & 3.2 & 3.3 & 3.4 & 3.5 \\
\hline Number of families & 98 & 97 & 97 & 97 & 95 & 94 & 91 & 90 & 84 & 77 & 63 & 54 & 38 & 20 & 16 & 8 & 4 \\
\hline Number of trees & 1277 & 944 & 879 & 803 & 696 & 571 & 477 & 369 & 280 & 209 & 140 & 90 & 48 & 24 & 18 & 9 & 4 \\
\hline $\begin{array}{c}\text { Selection intensity, } \\
\%\end{array}$ & 100 & 73.9 & 68.8 & 62.9 & 54.5 & 44.7 & 37.4 & 28.9 & 21.9 & 16.3 & 11 & 7 & 3.8 & 1.9 & 1.4 & 0.7 & 0.3 \\
\hline $\begin{array}{c}\text { Status number, } \\
N_{S}\end{array}$ & 317 & 265 & 259 & 254 & 241 & 225 & 208 & 179 & 153 & 128 & 95 & 70 & 43 & 22 & 17 & 9 & 4 \\
\hline $\begin{array}{c}\text { Gene diversity, } \\
\text { GD }\end{array}$ & 0.998 & 0.998 & 0.998 & 0.998 & 0.998 & 0.998 & 0.998 & 0.997 & 0.997 & 0.996 & 0.995 & 0.993 & 0.988 & 0.977 & 0.971 & 0.941 & 0.875 \\
\hline $\begin{array}{c}\text { Inbreeding } \\
\text { coefficient, } F\end{array}$ & 0.0016 & 0.0014 & 0.0014 & 0.0013 & 0.0014 & 0.0014 & 0.0014 & 0.0014 & 0.0015 & 0.0015 & 0.0017 & 0.0016 & 0.0012 & 0.00180 .00160 .0035 & 0 \\
\hline $\begin{array}{c}\text { Selection } \\
\text { differential, S (m) }\end{array}$ & 0 & 0.24 & 0.27 & 0.31 & 0.37 & 0.44 & 0.49 & 0.57 & 0.64 & 0.7 & 0.78 & 0.86 & 0.96 & 1.07 & 1.12 & 1.2 & 1.28 \\
\hline $\begin{array}{c}\text { Genetic gain, } \Delta G \\
\text { (cm) }\end{array}$ & 0 & 4.3 & 4.9 & 5.6 & 6.7 & 7.9 & 8.8 & 10.3 & 11.5 & 12.6 & 14 & 15.5 & 17.3 & 19.3 & 20.2 & 21.6 & 23 \\
\hline $\begin{array}{c}\text { Genetic gain, } \Delta G \\
(\%)\end{array}$ & 0 & 1.9 & 2.1 & 2.4 & 2.9 & 3.4 & 3.8 & 4.5 & 5 & 5.4 & 6.1 & 6.7 & 7.5 & 8.3 & 8.8 & 9.3 & 10 \\
\hline
\end{tabular}

sion would be negligible. At first glance it is surprising that $F$ remains consistent over a broad range of selection intensities. However the limited number of retained trees within a family plays a major role. When one tree remains in a family there cannot be any half-sib mating, and if two trees remain, the frequency of half-sib mating is reduced to half of what it would have been if there were large half-sib families. The retention of a large number of families and a small number of individuals within those families across a broad range of selection intensities results in a stable inbreeding coefficient and a correspondingly high $N_{s}$. For example, at the $3.8 \%$ selection intensity 48 trees from 38 different families were retained and $N_{s}=43$.

Variation in reproductive output occurs among individual trees reducing the effective number in an orchard or stand (VARGHESE et al., 2002). Based on a literature review of flowering variation in stands, KANG (2001) suggested that variation in reproductive output could be accounted for by inflating the group coancestry by a factor of two, or decreasing $N_{s}$ by half compared to estimates obtained under the random mating assumption. Operationally, differences in reproductive output can be mitigated by collecting an equal number of seeds from each tree (BILA et al., 1999).

Selfing in Scots pine occurs at very low levels. Estimates of multi-locus outcrossing rates indicate that over $97.0 \%$ of seedlings will be of an outcrossed nature (BurCzyK, 1998; BurCZYK and ChAluPKA, 1997). These low levels of selfing would not appreciably increase inbreeding depression in gene resource plantations because in conifers most selfed seed are aborted early due to an accumulation of lethal recessives. Moreover, selfed seedlings suffer from a lack of vigor and could be culled from nursery stock prior to planting.

Like the inbreeding coefficient, gene diversity, $G D$, was relatively stable across a wide range of selection intensities and genetic gain estimates (Fig. 3). Steep

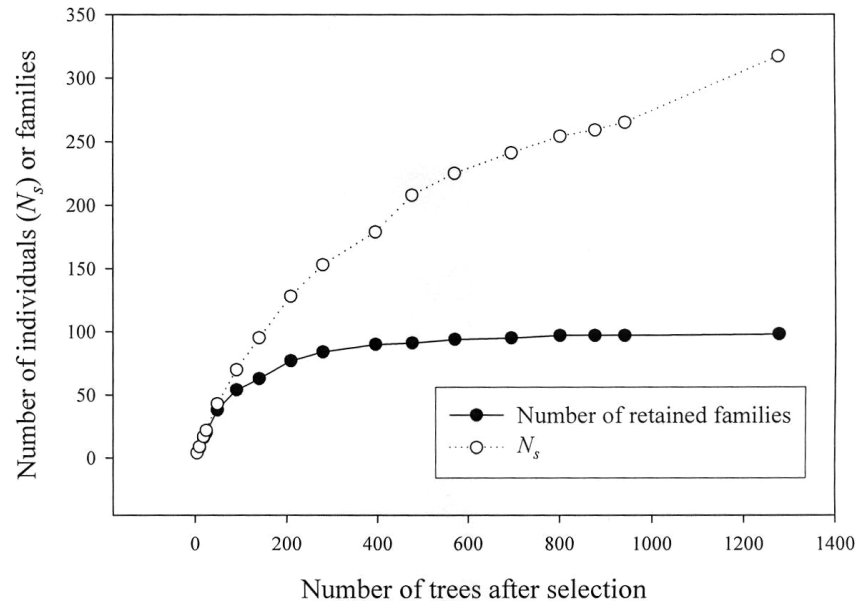

Figure 1. - Impact of truncation selection on $N_{s}$ and the number of families in a 98 family half-sib Scots pine progeny plantation. Each point represents a different selection intensity.

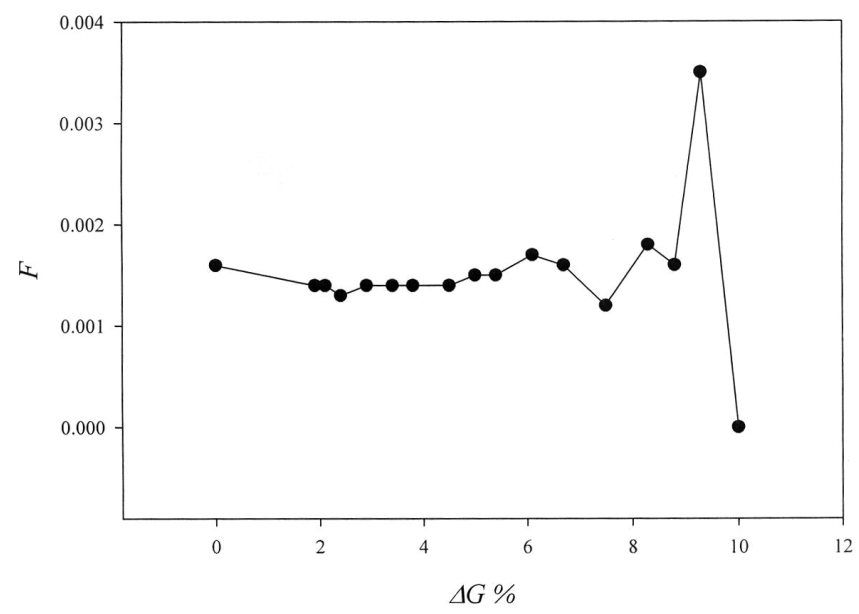

Figure 2. - Relationship of predicted inbreeding coefficient in seed harvest $(F)$ to estimated genetic gain $(\Delta G)$ for height in a 98 family half-sib Scots pine progeny test. Each point represents a different selection intensity. 


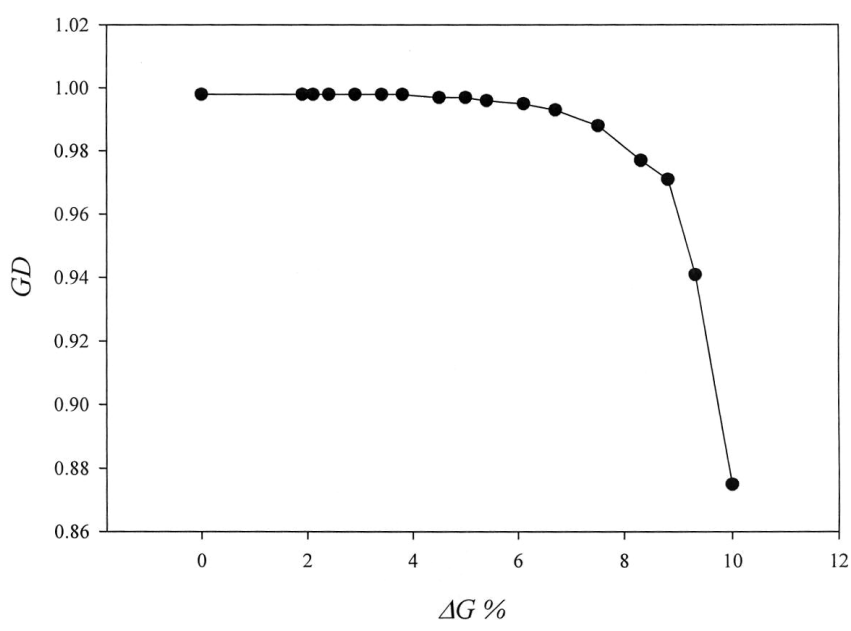

Figure 3. - Relationship of gene diversity $(G D)$ to estimated genetic gain $(\Delta G)$ for height following rogueing in a 98 family half-sib Scots pine progeny test. Each point represents a different selection intensity.

losses in gene diversity occurred only at the highest selection intensities when $N_{s}$ dropped below 43 (Table 1). Although gene diversity is negatively affected by selection intensity and drops rapidly at the highest selection intensities it will be positively affected by pollen flow into the plantation. Pollen immigration would have the greatest impact on $\Delta G, F$ and $G D$ at the highest selection intensities when $N_{s}$ is relatively low, and for this reason the highest selection intensities are unrealistic for operational activities.

To estimate $F$ this analysis assumed that all original parents were unrelated which is consistent with the practice of assuming the initial generation is unrelated with an inbreeding coefficient of zero (FALCONER, 1989). Because the original parents for this study were selected across a wide geographic area the initial reference generation can be regarded as unrelated and the calculated inbreeding coefficient is the addition of relatedness since the initial selections.

This analysis also assumed that the seedlings in the progeny trial were true half-sibs, i.e. seedlings within a family all had different pollen parents, which may not be completely accurate. Open-pollinated families may contain individuals with the same pollen parent, which results in full sib status and an increase in the actual average pair coancestry. Additionally, the half-sibs come from different populations and widely separated seed parents which are "more unrelated" than the pollen parents within a half-sib family. This also raises the coancestry within family somewhat. We believe the quantitative effects of these cases to be small and unlikely to change the fundamental findings of this research. The possibility that the actual average pair coancestry can be somewhat higher than calculated strengthens the need for working with many families and limited selection intensities when applying this technique to gene resource populations.

These results indicate that low input options for tree improvement do exist in gene resource populations assuming 1 ) the seedlings are derived from a sufficiently large number of unrelated selections and 2) selection results in the retention of a large number of families represented by a small number of individuals. In our example truncation selection retained an appropriate number of families and individuals within families to meet the second assumption. Other genetic resource plantations may require a different selection method such as family plus within family selection to meet this assumption (and correspondingly different methods of calculating estimated genetic gain). Because each genetic resource population might have its phenotypic variation structured differently the various genetic gain, genetic diversity and inbreeding parameters will have to be calculated for each case to determine a feasible selection intensity. For genetic resource plantations that meet these two assumptions rogueing will result in appreciable genetic gains combined with high levels of gene diversity and a low inbreeding coefficient. The remaining trees can then be used to establish a seed production area and/or contribute to a long term breeding program.

\section{Acknowledgement}

This study has been financially supported by Föreningen Skogsträdsförädling. We are very thankful to ToRGNY PERSSON and SkOGForsK for data of field measurements. Dr. DARIUS DANUSEVIČIUS is acknowledged for constructing the computer program used for simulation of truncation thinning.

\section{References}

BARnes, R. D. (1995): The Breeding Seedling Orchard in the Multiply Population Breeding Strategy. Silvae Genetica 44(2-3): 81-88.

BilA, A. D., D. LindGren and T. J. Mullin (1999): Fertility variation and its effect on diversity over generations in teak plantation (Tectonia gradis L.f.). Silvae Genetica 48(3-4): 109-114.

BURCZYK, J. (1998): Mating system variation in a Scots pine clonal seed orchard. Silvae Genetica 47(2-3): 155-158.

BuRCZYK, J. and W. CHALUPKA (1997): Flowering and cone production variability and its effect on parental balance in a Scots pine clonal seed orchard. Ann. Sci. For. 54(2): 129-144.

Durel, C. E., P. Bertin and A. Kremer (1996): Relationship between inbreeding depression and inbreeding coefficient in maritime pine (Pinus pinaster). Theor. Appl. Genet. 92(3-4): 347-356.

FALCONER, D. S. (1989): Introduction to quantitative genetics. Third edition. John Wiley and Sons, New York, New York. 438 pp. ISBN 0-470-21162-8.

Gilmour, A. R., B. R. Gullis, S. J. Welham and R. ThompSON (2001): ASREML reference manual. 246 pp. NSW Agriculture, ORANGE, 2800, Australia.

Harwood, C. E., D. G. Nikles, P. Pomroy and K. Robson (1996): Impact of thinning via phenotypic selection on the genetic base of planted seed production areas, pp.148-153. In: Tree Improvement for sustainable tropical forestry, edited by M. J. Dieter, A. C. MATHESon, D. G. Nikles, C. E. Harwood and S. M. Walker, Proc. QFRI-IUFRO conf, Caloundra, Queensland, Australia, 27 October to 1 November 1996. 
KANG, K. S. (2001): Genetic gain and gene diversity of seed orchard crops. Ph. D. dissertation. ISSN 1401-6230, ISBN 91-576-6071-9

Krusche, D., B. L. DAS and B. R. Stephan (1980): Results of a progeny test with Pinus sylvestris and estimation of genetic gains from different selection methods. Silvae Genetica 29(3-4): 122-129.

LindGren, D., L. D. GeA and P. A. Jefferson (1996): Loss of genetic diversity monitored by status number. Silvae Genetica 45: 52-59.

LINDGREN D. (2000): Low-intensity tree breeding, pp. 37-48 in Rapid generation turnover into the breeding population and low-intensity breeding, edited by $\mathrm{K}$. LUNDKVIST, Research Notes 55, Department of Forest Genetics, Uppsala, SLU, Sweden. ISSN = 0348-565X.

LINDGREN, D. (2003): Low-input tree breeding strategies. In: Eucalyptus Plantations - Research, Management and Development, R.-P. WEI and D. XU (eds), World Scientific, Singapore, 149-166.

MATHESON, A. C. and C. A. RAYMOND (1984): Effects of thinning in progeny test on estimates of genetic parameters in Pinus radiata. Silvae Genetica 33(4-5): $125-128$.
PERSSON, T. (1999): Svenska plusträdskloner från 1980 års plusträdsurval till förädlingspopulations Tpop 7 . Avelsvärden 68. SkogForsk. S-751 83 UPPSALA, Sweden.

SorEnsen, F. C. (1997): Effects of sib mating and wind pollination on nursery seedling size, growth components, and phenology of Douglas-fir seed-orchard progenies. Can. J. For. Res. 27(4): 557-566.

Squillace, A. E., J. G. A. La Bastide and C. L. H. VAN VREDENBURCH (1975): Genetic variation and breeding of Scots Pine in the Netherlands. For. Sci. 21(4): 341-352.

Varghese, M., N. Ravi, S.-G. Son and D. LindGREN (2003): Variation in fertility and its impact on gene diversity in a seedling seed orchard of Eucalyptus tereticornis, pp. 46-60 in Proceedings from Symposium on Eucalyptus plantations, Sept 1-6, 2002, Guangdong, China.

Wu, H. X., A. C. Matheson and D. Spencer (1998): Inbreeding in Pinus radiata. I. The effect of inbreeding on growth, survival and variance. Theor. Appl. Genet. 97(8): 1256-1268.

\title{
Cone Yield Characterization of a Stone Pine (Pinus pinea L.) Clone Bank
}

\author{
By S. MUtKE ${ }^{\text {a) }}$, J. GoRDo ${ }^{\text {b) }}$ and L. GIL ${ }^{\text {a),*) }}$
}

(Received $11^{\text {th }}$ April 2005)

\begin{abstract}
In spite of the use of the edible kernels of Stone pine (Pinus pinea L.) gathered from Mediterranean pine forests, the species remains a genuine forest tree that has never been domesticated as an orchard crop. In the last decades, some efforts have been made to select valuable genotypes for exploring the possibilities of Stone pine as an orchard crop. The present paper characterizes the cone yield of a grafted clone bank in order to elucidate the relevance of genetic and environment factors for seed-yield quantity and quality and for sequential transition rates of the development from pollinated conelets to ripe cones. Individual tree size and cone yield were separated in their genetic and environmental components, in order to estimate phenotypic, genetic and environmental correlations. A statistical model for logtransformed individual cone yield was adjusted, ranking the tested genotypes by their estimated clonal value after adjustment for tree size covariables. The degree of genetic determination for adjusted cone yield was esti-

a) ETSI Montes, Universidad Politécnica de Madrid (Spain).

b) Servicio Territorial de Medio Ambiente, Junta de Castilla y León.

*) Prof. Dr. Luis Gil, ETSI Montes, Universidad Politécnica de Madrid, Ciudad Universitaria, E-28040 Madrid (Spain).

Tel.: (+34) 91336 5039, Fax: (+34) 91 3366386, E-mail: lgil@montes.upm.es
\end{abstract}

mated in $15 \%$, the expected genetic gain by selection of the top $10 \%$ of tested genotypes would be $12 \%$. Genetic correlation between genetic values for cone yield and cone and seed size were weak but significantly positive ( $r=0.27$ and 0.17 ), hence the lack of trade-offs between crop quantity and quality will allow a combined selection.

Key words: Mediterranean stone pine, pine nuts, cone survival, degree of genetic determination.

\section{Introduction}

Since the Palaeolithic period, humans have gathered the cones of the Mediterranean Stone pine for their large edible kernels (GIL, 1999; BADAL, 2001). Scattered populations of the species range all over the Mediterranean countries, though the most extensive native forests grow in the Iberian Peninsula (THIRGOOD, 1981; PRADA et al., 1997). Despite of its interest as a nut tree, Stone pine has never been domesticated but remains a genuine forest tree and the cone yield is gathered from forest stands. About $70 \%$ of the world production comes from Spain and Portugal. At present, pine nuts are in increasing demand on the international market due to their delicate flavour and high nutritional value with $30 \%$ proteins and $50 \%$ fats, more than $80 \%$ of them 